\title{
EREBEA
}

Revista de Humanidades

y Ciencias Sociales

NúM. 1 (2011), pp. 103-136

ISSN: 0214-0691

\section{SOBRE EL TRASFONDO SOCIAL DE LA PREDICACIÓN mendicante en Castilla y León (Siglo XIII)}

\author{
Javier Pérez-Embid Wamba \\ Universidad de Huelva
}

\section{RESUMEN}

El artículo se propone extraer la información histórico social a dos fuentes relativas a predicación, compuestas en la España del siglo XIII: los índices añadidos al Vitas sanctorum, de Rodrigo de Cerrato, y los sermones ad status contenidos en el sermonario de Juan Gil de Zamora. El orden en que el dominico castellano disponía los "exempla" tomados de su legendario hagiográfico para la preparación de sermones muestra un mayor énfasis en el adoctrinamiento del clero que del mundo laico y, en todo caso, una concepción moral acorde con el momento de la evolución teológica de su tiempo. Los sermones del franciscano ofrecen siempre, dentro del molde retórico, unos panoramas de la situación moral contemporánea que, aun exentos de matices "nacionales", se han transcrito en buena medida como fuentes que son para la historia del análisis y crítica sociológica.

Palabras Clave

Sermones, Predicación, Mendicantes, Exempla, Crítica Social.

Fecha de recepción: 1 de abril de 2011

Fecha de aceptación: 15 de abril de 2011

\section{Abstract}

The article explores social and historical information of two sources related to preaching in $13^{\text {th }}$ century Spain: the added indexes to Rodrigo de Cerrato's Vitas Sanctorum and the sermons ad status included in Juan Gil de Zamora's sermons book. The Castilian Dominican structures the "exempla" that took from his legendary hagiographical work are ordered in such a way that more emphasis falls on education of the clergy and less in the world of laymen. He exposes a moral conception in accordance with the teological evolution of his time. The sermons of the Franciscan, conceived undoubtedly with rhetorical patterns, offer systematically a panoramic view of the moral contemporary atmosphere of his time, and even if they lack "nationalistic" nuances, they have been transcribed as sources for the history of analytical and sociological criticism.

\section{KEYWORDS \\ Sermons, Preaching, Mendicants, Exempla, Social Critiscism.}



La hagiografía es, sin duda, una fuente para el estudio de la predicación de los frailes mendicantes durante el siglo XIII, durante el cual algunos de los más destacados miembros de aquellas órdenes fueron promovidos a la canonización. Vitae y miracula permiten,así, al historiador perfilar las condiciones en que aquella predicación se realizaba, al servicio de la catéquesis o adoctrinamiento cristiano del pueblo ${ }^{1}$. Nuestra intención en este artículo consiste, más bien, en buscar una aproximación al contenido y al contexto de esa predicación, a través de la obra hagiográfica de un dominico castellano, Rodrigo de Cerrato, y de la de un franciscano leonés, Juan Gil de Zamora ${ }^{2}$, así como, principalmente, de los sermones compuestos por éste último.

El primero es un predicador vinculado al convento de Segovia del que casi todo lo que se conoce son conjeturas: una posible estancia (¿de formación?) en la casa de Toulouse, una asistencia al capítulo general de la orden en 1246, un viaje a la Andalucía bética hacia 1270 (en relación probable con el arzobispado en Sevilla de su hermano de religión-y anterior obispo de Segovia- Remondo, o Raimundo, Lausannensis), y, en 1272, cierta tutela sobre las monjas dominicas del convento de Caleruega. Salvo esta circunstancia, lo demás se deduce del legendario que compuso, resultado de varias ediciones entre 1260 y $1276^{3}$, y en cuyo prefacio dejó explícita la finalidad de auxiliar de la predicación que asignaba a la obra:

\footnotetext{
"Vitas sanctorum, nimia prolixitate descriptas, ac variis voluminibus dispersas, quorum festa ecclesia colit, vel quorum historias fides fidelium recipit, breviter et succincte eligens utilia in uno volumine prestringere curavi, explosis coloribus purpuratis. Quatinus prolixitas, mater tedii, lectorem non
}

1 Cf. A. García de la Borbolla, Algunas consideraciones... (artículo antecedente en esta misma obra); de la misma autora, "La praesentia" y "la virtus": la imagen y la función del santo a partir de la hagiografía castellano-leonesa del siglo XIII. ("Studia Silensia", XXIV). Abadía de Silos, 2002.

2 Sobre ambos, cf. J. Pérez-Embid Wamba, Hagiografía y sociedad en la España medieval. Castilla y León (siglos XI-XIII). Universidad de Huelva, 2002, respectivamente, en p.215-255 y 303-364.

3 Se contiene en los siguientes códices: Bib. Cap. Segovia, vit. 28; Bib. Universidad Complutense, mss 146(s. XIV); Bib. Nationale (Paris), Lat 23333 y 2333A (s. XIII y XIV); British Museum , Add.30057 (s.XIV) y 23935 (s.XIII); Bib. Publique (Toulouse),ms. 82. La memoria personal del Cerratense parece remontarse a 1237, y se emplea en datar acontecimientos de la década de los años cuarenta y cincuenta (cf.Pérez-Embid, Hagilogía y sociedad...,p. 243-254. 
retrahat et brevitas alliciat, utilitas inducat, color rhetoricus non obducat, et predicatoribus vero ad predicandum de sanctis non desit materia, et ad excitandam materiam devotionem fidelium devota inveniatur exempla; clericos quoque inopes ad habendum vitas sanctorum inopia non excuset”".

Se trataba, pues, de que no faltase materia a los predicadores que, en el ejercicio de su actividad, utilizan las vidas de los santos para excitar, a través del ejemplo, la devoción de los fieles. Y con el fin -añade- de que los clérigos, en su inopia, no hallasen excusa para no llevar una vida santa.

De forma que, siguiendo el orden calendario, y proponiéndose la concisión y el realismo, el fraile palentino realizó un trabajo de concordancia de fuentes y de abreviación que tuvo como resultado la edición de 158 leyendas de santos sobre un total de 230 folios en uno de los códices. Un nuevo santoral, basado en la evolución litúrgica y teológica de entre 1260 y 1275 , en el que el incremento de los santos romanos y orientales deja a los hispanos con una cuota de protagonismo del $15 \%$, y donde la modernidad puede deducirse de reservar para los mártires sólo el $56 \%$ del espacio historiado, en un siglo en que éstos venían ocupando alrededor del $75 \%$ en las diversas colecciones de leyendas ${ }^{4}$. Actualidad que le confiere igualmente el procedimiento seguido de explanar racionalmente la liturgia, en la línea de Juan Beleth y de la Legenda Aurea, con una exposición, "per circulum anni”, de las distintas festividades del temporal litúrgico.

Esto último termina por acreditar la funcionalidad predicadora del Vitas. Pero, por si ello resultara poco evidente, tras el explicit del vitas sanctorum con que concluye el códice de Segovia la leyenda de Juan el Patriarcas, el mismo "scriptor" (veremos como parece claro se trata del mismo Rodrigo de Cerrrato) añadió entre los folios $222 \mathrm{r}^{\mathrm{O}}-\mathrm{v}^{\mathrm{o}}$ un florilegio de "exempla" destinado a facilitar la consulta del legendario por parte de los predicadores. Y lo justifica con el siguiente preámbulo:

"Quoniam omnis homo sibi similem diligit et exemplis sibi similium a dissimilibus facilius retrahet, et exemplis sibi similium cicius informatur, idcirco secundum conditiones et genera hominum predicanda sunt exempla et uita sanctorum".

Ofrece, pues, un listado de posibles destinatarios de "exempla", tomados éstos de la hagiografía que él compendia en su legendario, y lo distribuye según los distintos "status" que percibía en la sociedad de su tiempo, tabla que ofrecemos a continuación ${ }^{6}$ :

4 Hagiología y sociedad...,p. 228.

5 "Hoc enim miraculum omnes viderunt qui eius sepulture interfuerunt, gratias agentes Deo qui mihi licet indigno dedit incipere et perficere librum istum quem Vitas sanctorum intitulaui. Qui incipit et explicit Vitas sanctorum" (Cód. Segoviense,fo 223 ro).

6 Traduciéndolo del latín y obviando las citas de ubicación de cada exemplum en el códice, ya 
- Arzobispos : Isidoro, Ildefonso, Tomás mártir

- Obispos : Martín, Nicolás, Hilario, Remigio, Dionisio, Agustín

- Deanes : en la vita de Santo Domingo y en la de San Bernardo

- Arcedianos : Esteban, Lorenzo, Vicente

- Presbíteros : Carpio, Jerónimo, Emiliano (Millán), Félix, Marco

- Abades : Benito, Bernardo, Gil, Furseo

- Abadesas : Brígida, Basilisa

- Monjes : Jerónimo, Román, Martín

- Monjas : Eugenia, Eufigenia ( $c f$. San Mateo,fo 7vo)

- Religiosos : cf. un exemplum en San Martín y dos en San Gregorio

- Eremitas : Pablo, Antonio, Jerónimo

- Reclusos : Pelayo y Remigio

- Reyes : Barlaam y otro en San Bartolomé

- Reinas. Una en Santa Catalina y otra en la del apóstol Tomás

- Soldados : Jorge, Hipólito, Martín.

- Nobles : Clemente, Ildefonso, Jorge, Isidoro, Alejo

- Seglares : Tiburcio y Valeriano, y otros en Santa Cecilia, Facundo y Primitivo, Juan y Paulo, Justa y Rufina, Cristóbal y los Siete Durmientes.

- Jueces : en la vida de Juan el Limosnero.

- Varones casados : en Santa Ana y San Joaquín, Juan Bautista,Adrián y Natalia, Dionisio y Pelagia y el apóstol Tomás.

- Mujeres casadas : Cecilia, Macidia y Teodora (en San Clemente)

- Viudas : Natalia (en San Adrián), Anastasia

- Vírgenes : Eufemia, Tecla, Justina, Once Mil Vírgenes, Catalina, Inés et cetera

- Niños : Pelayo, Josafat, Nicolás, Domingo

- Niñas : en la Asunción de la Virgen, et omnia que de virginibus dicta sunt

- Pobres : en la vida de Barlaam

- Hospitaleros : en las vidas de Silvestre, Germán y Marta

- Peregrinos : en María Magdalena, María Egipcíaca, Remigio, Dorotea y Julián

- Afligidos y atribulados : Eustaquio, Alejo, Martín, Anastasia, Antonio y Gil

- Tentados por la carne : Justina virgen, Jerónimo, Benito, Bernardo

- Enfermos : en las vidas de Germán y de Petronila, más algunos otros ${ }^{7}$

que la transcripción literal del texto se halla en la edición de la obra pr F. Villamil Fernández,Vitas sanctorum. Rodrigo de Cerrato Estudio y edición (edición en microfichas). Santiago de Compostela, 1991, p. 613-620.

7 " in consolationem presentem, dicantur que afflictis et tribulatis dicta sunt. Ad confortandam autem spem dicantur que de norte iustorum preciosa dicentur" ( $c f$. supra et infra). 
Tal agrupación de lugares donde hallar los exempla debía servir como instrumento para la elaboración de los sermones "ad status", subgénero que el dominico elaborador del índice parece considerar en primer término. La distribución entre las categorías sociales percibidas por el dominico de Segovia no es fruto de afinidades subjetivas ni debidas al azar. Al iniciar la escala social por los arzobispos, un eclesiástico del entorno del rey Alfonso X (en dialéctica política con el papado) no podía menos de fijarse en primer término en las figuras «nacionales » de San Isidoro y Sal Ildefonso, pero sólo para, a continuación, añadir , con Tomás Beckett,el icono de la iglesia romana antiregaliana. En esa línea, y en general, es lógico que represente a los obispos con las figuras estelares del episcopado galo y romano, desde San Martín a San Agustín. En los escalones inferiores de la jerarquía eclesiástica (arcedianos, presbíteros) puede percibirse todavía la huella hispana, que -aun brotando de nuevo entre los nobles- desaparece del todo al abordar el mundo de los monjes y los religiosos. El hagiógrafo parece atenerse a las figuras de origen oriental bajo cuya paternidad hacía siglos se colocaban otras tantas opciones religiosas, el eremitismo, el cenobitismo o incluso la milicia.

No acaban, sin embargo, del todo las presencias hispanas, pues entre los seglares vemos incluirse las parejas de mártires Facundo y Primitivo y Justa y Rufina, enseńas patronales en dos centros axiales de la España reconquistada al islam de hacia 1270, el santuario del Cea (principal entre los cluniacenses de Castilla) y Sevilla. Y aun más llamativo es que el San Pelayo que encabeza los "exempla» referentes a niños sea el mismo mártir de Córdoba cuya passio se integró en el llamado «Passionario Hispánico», y no el San Pelagio papa al que se refiere la Legenda Aurea ${ }^{8}$.

La tónica, sin embargo, es adoptar como figuras icónicas, ejemplares, a otros tantos santos que veremos reaparecer recurrentemente en el segundo florilegio, y por diversos conceptos.

Y si tal clasificación había tenido por objeto preparar la predicación en función del principio de la similitud (de la condición social o humana, se entiende), a continuación el Cerratense dispuso otro florilegio de exempla destinado a inflamar en el pueblo el anhelo de la patria celestial por la siembra de virtudes y la extirpación de vicios :

«Sicut in primo Dialogorum ait Gregorius et nos cotidie in libro experiencie legimus, sunt nonnulli quos ad amorem patrie celestis plus exempla quam predicamenta succendunt, idcirco exempla que in vitis sanctorum scripsi per alphabetum breviter notare curaui, quatinus ad predicte patrie

8 Jacobo da Varazze inserta, no obstante, en esta leyenda un relato de la vida y doctrinas de Mahoma (cf.. S. de la Vorágine,La Leyenda Dorada. Madrid, 1995,2,p.803-822). 
desiderium succedendum, ad uirtutes quoque plantandas et ad uicia extirpanda conueniencia inveniantur exempla»?

1- El amor de Dios hacia los pecadores : «visio » de Carpio

2- La amistad de los santos hacia los diligentes : en Margarita, Cosme y Damián, Juan y Pablo, Nicolás, Santiago el Mayor, Francisco, Bartolomé y Tomás mártir.

3- El amor de los justos hacia Dios : en la vida de Ignacio y en las de todos los mártires

4- El amor de los justos hacia el prójimo: Juan Evangelista, Santo Domingo

5- El amor de los justos hacia los pecadores: Juan Evangelista, Juan el Limosnero

6- El amor de los justos hacia los enemigos :Esteban, Santiago el Menor

7- El amor carnal hacia los consanguíneos : Conmemmoración de los Fieles Difuntos

8- La falsa amistad : en la vida de Barlaam

9- El adulterio : Andrés, Tomás mártir, San Pedro Ad Víncula, en la Degollación

10- Los apóstatas : San Juan Evangelista, Asunción de la Virgen

11-Aparición póstuma de los santos : en San Pedro y San Pablo

12- Las almas de los santos que en su muerte se vieron bajo diversas especies : Cecilia, Escolástica, Benito, Asunción de la Virgen

13- La pérdida de las cosas temporales :Bernardo, Juan el Limosnero

14- La avaricia : Furseo, Antonio, Asunción de la Virgen, Juan el Limosnero

15- Contra los demasiado austeros : San Juan Evangelista

16-El bautismo : Cecilia, Silvestre, Epifania, Remigio, el otro Ginés

17 -Reconocimiento de un beneficio : Jerónimo, Blas, Barlaam

18- Blasfemia : Asunción de la Virgen

19- Castidad : Cecilia, Clemente, Anastasia, Paulo, Inés, Asunción de la Virgen, Bernardo, Pentecostés.

20- De oráculos o predicciones : Bernardo

21- La constancia de los justos : en la vida de todos los mártires, especialemente Tomás, Sebastián, Vicente, Lorenzo, Ignacio, et cetera.

22- La astrología ${ }^{10}$ : Clemente (en Post hoc)

23- La conversación santa : Martín, Pedro apóstol, Germán, Bernardo, Marta, María Egipcíaca, Asunción de la Virgen, Santiago

24- El Cuerpo de Cristo : Gregorio, Tomás Mártir, Tomás Apóstol, Domingo, Sagrada Cena

25- Comunicación del Cuerpo de Cristo :Lucía, Dionisio, María Egipcíaca,

9 Cód. Segoviense, fo $222 v^{\circ}-223 r^{\circ}$. En la lista que ofrecemos a continuación traducimos igualmente las rúbricas y eludimos la cita del pasaje en que comienza cada exemplum, dado que se hallan transcritos (por indicación del párrafo en que comienzan) en la edición de Villamil Fernández, Rodrigo de Cerrato...,.,p. 615-620

10 "De constellatione" en cód. Seg.,fo223vo(Villamil,Rodrigo...,p. 616). 
Santiago, Damián, Asunción.

26- Comunicaciones indignas : Gregorio

27-Comunicaciones (o revelaciones) : Silvestre, Hilario, Antonio, Asunción de la Virgen

28- Curiosos : Clemente, Genoveva, Bernardo

29- Cruz : Invención de la Cruz, Exaltación de la Cruz, Justina, Martín, Juan y Pablo, Silvestre, Benito.

30- Crueldad : Inocentes, Once Mil Vírgenes

31- Delectación carnal o mundana : Barlaam

32-Detractores : Bricio, Gregorio, Benito, Ambrosio

33- Difamados y difamantes : Macario, Pafnucio

34- Contra las delicadezas: Alejo, Germán, Juan el Limosnero

35- Contra los desesperados : Pelagia, Cipriano

36- Contra los burladores : Bricio, Ambrosio

37- Disciplinas : Santo Domingo

38- Lamentar lo perdido : Barlaam

39- Frecuentar la iglesia : Nicolás, Juan el Limosnero, Juan y Pablo

40- Celebrar las fiestas : Asunción de la Virgen

41- Cometer fraude : Nicolás

42- Ebriedad : Nicolás

43-Limosna : Martín, Nicolás, Tomás Apóstol, Tomás Mártir, Jorge, Benito, Pedro apóstol, Germán, Santo Domingo, Juan el Limosnero

44- Limosna por los Difuntos: Juan el Limosnero

45- Hospitalidad : Clemente, Silvestre, Santa Marta

46- Honrar las reliquias de los santos : Once Mil Vírgenes, Juan el Limosnero

47- No honrar al santo no canonizado : Martín

48- Honrar a los justos : Martín

49- Honrar los lugares santos: Arcángel San Miguel

50- Honrar a los obispos: Pasión de Cristo

51- Honrar a los pobres: Barlaam

52- Humildad: Exaltación de la Cruz, Eustaquio, Hilario, Germán

53-Ayuno: Nicolás, Andrés, Juan Evangelista, Silvestre, Asunción de la Virgen

54-Enfermos que consultan a los demonios: Andrés

55- Falsos juramentos: Nicolás

56- Contra jueces: Asunción de la Virgen

57- Juicios: Juan el Limosnero

58- Agradecidos por beneficios: Jerónimo, Macario

59- La impiedad en los pobres: Gregorio

60- Envidia: Benito

61- Ignorar las difamaciones: Simón y Judas, Bricio, Genoveva, Antonio, Pafnucio

62- Lágrimas: Agustín

63- Las faltas leves: Difuntos

64- El vicio de la lengua: Benito 
65- El mal juego: Bernabé, Asunción de la Virgen

66- Mensajes por aves: Difuntos, Andrés, Anastasia, Eugenia, Remigio, Asunción

67- Quien procura el mal para alguien cae en él: Eufemia, Ambrosio, Pedro Apóstol

68- La maldición materna: Esteban

69- Devoción al martirio: Adrián y Natalia, Eufemia, Mauricio

70- Celebración de la misa: Gregorio, Asunción, Jueves Santo, Difuntos

71- Misericordia: Juan el Limosnero.

72- La valiosa muerte de los justos: Dionisio, Martín, Andrés, Nicolás, Juan Evangelista, Pablo el eremita, Hilario, Inés, Benito, Santo Domingo

73-La nefasta muerte de los malos: Eufemia, Tomás Mártir, Inocentes, Hilario, Julián, Juliana, Hipólito

74- La memoria de los muertos: Juan el Limosnero

75- El desprecio del mundo: Juan Evangelista

76- La concesión de préstamo: Juan el Limosnero

77- Evitar la compañía de mujeres: Barlaam, Remigio

78- La oblación: Difuntos

79- La oración: Martín, Clemente, Andrés, Nicolás, Silvestre, Elena, Escolástica, Isidoro, Santo Domingo, Antonino

80-La oración dominical: Once Mil Vírgenes, Santiago el Mayor

81- Qué oración no hay que dirigir a los santos: Tomás Mártir

82- Quienes no pueden estar en oración: Santo Domingo

83- El adorno de las mujeres: Bernardo

84-El odio: Ambrosio

85- La obediencia: Benito

86- Las buenas obras: La Asunción de la Virgen

87- La paciencia: Eustaquio, Bernardo

88- La pobreza: Alejo

89- La penitencia: Pelagia, María Egipcíaca, María Magdalena, Ambrosio, Remigio, Cristóbal

90- La pena del Purgatorio: Nicolás, Furseo, Margarita

91- El castigo de los malos: en la Pasión de Cristo

92- El castigo de los justos en la vida presente: Eustaquio

93- La pena del infierno: Macario

94- La predicación: Sebastián, Pedro y Pablo, Catalina, Mamés, Bernardo

95- Sobre golpes: Genoveva

96- Piedad: Silvestre, Santiago el Mayor, Jorge

97- Rapińa: Santiago el Menor

98- Resurrección: Siete Durmientes, Germán, Difuntos

99- La risa: Ambrosio, Asunción de la Virgen

100- La esperanza de la gloria futura: Bernardo

101- Simonía : Pedro apóstol, Cosme y Damián

102- Soberbia: Hilario, Exaltación de la Cruz

103- Supersticiones : Esteban 
104- Tentación de la Carne : Benito

105- Testimonio : Matías

106- Vana gloria : Pedro Apóstol, Pedro y Paulo, San Pedro Ad Vincula, Difuntos

107- La miseria de la vida presente : Barlaam

108- La vida presente de los justos : Eustaquio, Antonio

En este listado de exempla (cuyo orden alfabético se pierde al traducirlo del latín) se ignoran por completo los santos hispanos, dirigiéndose la atención del hagiógrafo hacia todas las categorías hagiológicas, apóstoles, mártires o confesores, en mayor medida los antiguos que los "modernos". La abundancia de milagros disponibles en algunas leyendas relativas a festividades litúrgicas permite el recurso a ellas, de forma más reiterada la Asunción de la Virgen. Y resulta notable la inclinación del Cerratense a procurar exempla en las leyendas de santos orientales nuevamente incorporados ${ }^{11}$, menos las de quienes podían ejemplificar aspectos contemplativos (como el abad Pafnucio o María Egipcíaca) que las de quienes ostentaban valores más generales, como Barlaam ${ }^{12}$, y sobre todo de actualidad social, como Juan el Limosnero.

La vita de Juan el Limosnero $(+619)^{13}$, patriarca de Alejandría venerado como un prodigio de beneficencia especialmente por parte de la orden del Hospital, es abreviada en el Vitas sanctorum del Cerratense con mayor número de milagros de los que le son atribuidos por la Legenda aurea, y de ellos toma el segundo índice exempla para once items ${ }^{14}$, desde la pérdida de las cosas temporales hasta la concesión del préstamo. Precisamente estos dos conceptos (que se cuentan entre los ignorados por Jacopo da Varazze) indican el sentido que Rodrigo de Cerrato entendía conferir a la leyenda del Limosnero. En el primero un mercader naufraga por malversar el dinero recibido del patriarca ${ }^{15}$, y lo mismo le ocurre una segunda vez por adquirir con malas artes la nave ${ }^{16}$. Pero recibe ahora de la iglesia un barco cargado con 21.000 modios de trigo, que los intercambia por un car-

11 Fenómeno relacionado con la reintegración de la iglesia oriental auspiciada en el concilio de Lyon de 1274 (Pérez-Embid,Hagiología...,p.222). Del primero (cuya vita no va seguida, excepcionalmente, de miracula) se toman 7 exempla (no 8,17,31,38,51,77 y 107).

12 De Pafnucio $c f .33,61$; de María Egipcíaca,no 23, 25 y 89; de Barlaam,no 8,17,31, 38, 51, 77 y 107.

13 Escrita por Leoncio de Neapolis.

$14 C f \mathrm{n}^{\circ} 13,14,34,39,43,44,46,57,71,74$ y 76 .

15 "Nauclerus quidam dampna pertulit et accedens rogavit beatum Iohannem cum multis lacrimis ut compateretur ei. At ille dedit $\mathrm{V}$ libras auri, qui emptis mercibus et missis in navim naufragium pertulit, sed navim non perdidit. Et veniens iterum petiit aliquid ab eo. Cui respondit:"Frater, nisi miscuisses peccuniis ecclesie pecunias que tibi remanserant naufragium non pertulisses. De malis enim habuisti eas et nunc perdite sunt cum his que fuerunt ex bonis" (Villamil,Rodrigo de Cerrato...,II, 604,13-19).

16 "Hoc tibi accidit quia ipsa navis tua ex iniustitia erat possessa" (ibiem,II, 604,II,27-28). 
gamento de estaño en una hambrienta Inglaterra. De regreso a Italia, un socio descubre la plata que se hallaba oculta en el metal, y allí surge el exemplum:"Hoc miraculum fecit Deus ut famulum suum ditaret et nauclero misericordiam predicaret". El segundo exemplum, "de mutuo dando", pone en escena a un "dux" renuente a prestar cincuenta libras a un necesitado. Tras consultar al patriarca, una visión le muestra el ciento por uno que se obtenía por las ofrendas al altar ${ }^{17}$. Asimilando el préstamo a interés a la donación piadosa o a la limosna, el Cerratense presenta una alternativa financiera, moralmente válida, en una Castilla ávida de numerario ${ }^{18}$.

El criterio moral se impone, pues, de manera explícita en el segundo índice. Tal como dice haber leído en el primero de los Diálogos de Gregorio el Grande, y en el libro de la experiencia ("cotidie in libro experiencie"), el orden alfabético que adopta para ordenar los ejemplos que sobre vicios y virtudes pueden hallarse en las vidas de los santos (exigencia metodológica básica en las artes memoriae de la escolática ${ }^{19}$ ) excluye la posibilidad de cualquier otro orden o clasificación. El autor intenta agrupar los valores o cualidades morales según su signo positivo o negativo, pero ello no elimina el aire promiscuo del conjunto. Prescindiendo, en todo caso, del orden alfabético, puede percibirse que, agrupadas por series, las entradas más numerosas son las referentes a vicios y virtudes. Entre los primeros, junto a los que serán catalogados como pecados capitales por la teología moral escolástica (avaricia, ira -o"crueldad"-, envidia, soberbia.....) figuran otros de perfil más particular (el fraude, la usura, la impiedad de los pobres, el mal juego, la vanagloria), que remiten al tipo de apostolado que la orden de los dominicos entendía ejercer sobre la población urbana ${ }^{20}$. De igual manera, entre las virtudes se ve obligado a distinguir seis formas del amor, en función de la personalidad de quien lo experimente, o a distinguir entre la paciencia y la obediencia, o entre la pobreza, la miseriordia, la limosna y la hospitalidad.

Vanguardia de una iglesia que había hecho del sacramento instrumento mayor de la redención, el Cerratense agrupa algunos "exempla" acerca del bautismo, la penitencia, la eucaristía y, de forma más particular, sobre la celebración de la misa y otras ceremonias litúrgicas. Igualmente distingue entre algunas formas de

17 Villamil,ibidem,609,5-27-

18 Tampoco se halla en la legenda aurea el milagro del "elemosinator"que se hizo robar por su hijo para dar limosna a los pobres, primero denarios y siliquas y luego tremisses, todo lo cual no le impidió enriquecerse (Villamil,ibidem, 611,28-47).

19 Cf. M. Carruthers, The Books of Memory. A Study of Memory in Medieval Culture. Cambridge University Press, 1998.

20 Sin duda en Castilla el discurso de los predicadores había de hacerse más general, menos específicamente "sociológico" que, por ejemplo, el de sus hermanos de Florencia, cuyo apostolado se dirigía de manera muy particular al "popolo grasso" (D.N.Lesnisck, Preaching in Medieval Florence. The Social World of Franciscan and Dominican Spirituality. University of Georgia Press, 1989,p. 176-8. 
castigos menores (e incluso de ciertas calamidades: $c f .13,38$ ), trasunto de un sistema penal de abolengo germánico, de las penas del Purgatorio y aun de la condenación eterna. Y como el material lo extrae todo de la hagiografía, no puede ignorar el papel de los santos en la economía de la salvación, desde la honra de sus reliquias o sepulcros hasta las intervenciones u oráculos póstumos ${ }^{21}$. Tema que emparenta con el de los difuntos y su memoria, al que dedica tres entradas (72, 73 y 74). En general, son más numerosos los "exempla" relativos al castigo de las faltas morales, que los referentes a aspectos ascéticos o místicos (no 15, 23, 29, 37, $53,75,79,80,86,98,108)^{22}$.

Ello no sorprende si se considera el Vitas sanctorum en el contexto de la evolución teológica acerca de los vicios y las virtudes. A fines del siglo XII y principios del XIII autores como Pedro el Cantor o Alain de Lille habían tratado de los mismos sin orden riguroso, y sólo la Summa de virtutibus et vitiis del obispo de París Guillaume de Auvergne (+1246) estableció cierto canon clasificatorio ${ }^{23}$. Pero es la obra del mismo título debida al dominico Guillaume Peyraut $(+1271)$ la que estimamos fuente directa del hagiógrafo castellano ${ }^{24}$, del mismo modo que otro dominico, Jacques de Benevent (+ post 1271) pudo inspirarle, con su Viridarium consolationis el primero de los índices añadidos al legendario. Y unos y otros predicadotres eran tributarios del modelo sermonístico establecido por el quinto general de su orden, Humberto de Romanos, quien en su De eruditione predicatorum liberó la predicación de la sujeción al texto bíblico para sustentarla en el razonamiento, apoyado no sólo en la Escritura sino también en la historia ${ }^{25}$. Los sermones ad status que integran los libros II y III de aquella obra servirían de modelo para la predicación de base sociológica. Y no nos cabe sino suponer que

21 E incluso la llamada a celebrar su fiesta de manera no espontánea, sino en el día acordado por la iglesia, según ejemplifica la visión ocurrida en los funerales de Tomás de Canterbury (Vitas... $\left.71 \mathrm{v}^{\mathrm{o}}-72 \mathrm{r}^{\mathrm{o}}\right)$.

22 "L'exposé des moyens permettant aux prédicateurs de susciter dans les auditeurs la crainte salutaire qui les amènera à renoncer au mal occupe une place nettement plus importante que celle réservée aux manifestations de l'amour de Dieu" (T. de Chobham, Summa de arte praedicandi. CCCM.Turnholt), Brepols, 1988; p. XLIII : apud "Introduction", de F. Morenzoni).

23 Cf. A. Solignac, "Vertus et vices", Dictionnaire de spiritualité, t. XVI. Paris, 1994,p. 498-506.

24 En las cinco partes del De virtutibus trata de las teologales y cardinales, y el De vitiis, editado en 1236 los divide en 9 tratados: "de vitiis in genere, gula, luxuria, avaritia, acedia, superbia, invidia, ira, peccata linguae". El último, que A. Solignac estima "novedad", puede ser la inspiración directa del "de lingue vitio" ( $c f$. supra el exemplum n o 64 del índice). Tomás de Aquino utilizará el "de virtutibus in conmuni”, primero de los tratados dedicados a las virtudes, para las questiones 1 a 2 a de laSumma de teología.

25 De ahí su impulso a la compilación de "exempla" (cf. S. Tugwell,OP,"Changing Attitudes Towards The Word of God", De l'homélie au sermon. Histoire de la prédication médiévale (J. Hamesse y X.Hermad, eds.). Louvain-la-Neuve, 1993,p. 159- 168. El De eruditione predicatorum, luego de sus ediciones de entre los siglos XVI al XVIII, se consulta hoy en la de J.J. Berthier, B. Humberti de Romanis Opera de Vita Regulari. 2 vols. Roma, 1888-1889. 
esa misma obra fuera el molde que Rodrigo de Cerrato , y sus hermanos castellanos, utilizaran para la confección de sus sermones.

\section{$\operatorname{cocs}$}

La orden franciscana proporciona en España una modalidad diferente del engarce entre la hagiografía y la predicación, gracias a la obra del polígrafo fray Juan Gil de Zamora (c. 1241-c.1318) ${ }^{26}$. Si dirigimos nuestra mirada al legendario alfabético que compuso no antes de 1289 y nos detenemos en su prefacio, advertimos que abrevió las leyendas de los santos "ut artificialius scribantur, subtilius habeantur, facilius inveniantur, forcius imprimantur, diutius et indelebius retineantur et custodiantur" ${ }^{27}$. Más adelante, tras dejar sentado el papel de la pobreza en la vocación franciscana, aclara que desea librar a sus hermanos del fardo que supone tener que cargar con libros a la hora de salir a predicar ("quia cum ad predicandum exeant tantum honus librorum secum deferre non possunt”). En otro lugar nos dice haber compuesto ya un liber sermonum, lo cual ilustra, también en este caso, la deliberada función ejemplar de la hagiografía.

Las 86 leyendas de santos de Gil de Zamora están menos abreviadas que las del Cerratense, por seguir un esquema prefigurado de antemano, con una serie de puntos a $\operatorname{tratar}^{28}$. En su conjunto, la escala de valores religiosos de los franciscanos se halla difuminada, en el santoral, porque el autor -según entendemos- quiso deliberadamente obviar el elemento propagandístico a favor de una exhortación más general hacia los valores cristianos ${ }^{29}$. Pero los "exempla" extraídos de las vitae no eran, como se verá, el único método de dilatar la estructura de un sermón.

El "frater Egidius, hispanus" que compuso el sermonario contenido en el códice 414 del fondo antiguo de la Biblioteca Comunale de Asís ${ }^{30}$, inédito aún,

26 Cf. Pérez-Embid,Hagiología y sociedad...,p. 303-365:"De la hagiografía a la historia nacional: la obra del franciscano Juan Gil de Zamora". Una actualización bibliográfica de la investigación referente a este autor, en C. Ferrero Hernández, Liber contra venena et animalia venenosa. Barcelona, 2009.

27 British Library. mss Add. 41070,fo $1 \mathrm{r}^{\mathrm{o}}$. Cf. F. Dolbeau,"Légendiers Latins ...,)Hagiographies, cultures et societéss. Actes du colloque de Nanterre.Paris, 1982,p. 24-25). Sobre la datación of supra (en este mismo volumen) F.Lillo Redonet,Las colecciones de sermones..., p. 85-6.

28 Cf. Hagiología y sociedad..., p. 307-309. Hay, en prensa, edición de las mismas a cargo de J.C. Martín Iglesias y E. Otero Pereira:Juan Gil de Zamora, "Legende sanctorum et festivitatum aliarum de quibus ecclesia sollempnizat".

29 Aún así, los referentes subjetivos o locales no están ausentes en el legendario, como se deduce de incluir en el mismo la passio de Santa Eulalia de Mérida (y no la de Barcelona); o de abreviar la leyenda de Cipriano de Cartago(ignorada por el Cerratense), en atención a los mártires franciscanos en Africa; la atención prestada a Santa Isabel de Hungría, por su parentesco con la reina Violante; o la extensión y acomodo" predicador "de Ildefonso de Toledo(Hagiología y sociedad..., p. 311-22). La misma percepción de algunas figuras del santoral hispano, como Domingo de Silos, difiere también respecto a la del Cerratense ( $c f . J$. Pérez-Embid, "Santo Domingo de siglos en la España del siglo XIII"(Abadía.III Jornadas de Historia en la abadia de Alcalá la Real.,p. 365-377)

$30 \mathrm{El}$ texto se halla hoy en internet y del mismo proceden todas las citas de folio y fragmentos 
se identifica hoy, sin duda alguna, con Juan Gil de Zamora. F. Lillo Redonet, que ha editado y traducido siete de los sermones "de tempore" 31 contenidos en aquél , distingue en el volumen dos obras diferentes, un Liber Sermonum (fo $3 \mathrm{r}^{\mathrm{o}}-216 \mathrm{r}^{\circ}$ ), que engloba 70 sermones, y un Breviloquium sermonum de vitiis et virtutibus ( $\mathrm{f}$ o $217 \mathrm{r}^{\mathrm{o}}-255 \mathrm{r}$ ). La primera contiene 32 sermones para ser predicados en las festividades del temporal litúrgico y de la Virgen, además de otros 21 dedicados a las de los apóstoles, los mártires, los confesores (simples y pontífices) y las santas vírgenes; y luego otros 17 destinados a ser predicados en distintas ceremonias y lugares, a razón de un par por cada una: las curias de los magnates, los conventos de religiosos, los sínodos diocesanos, las primeras misas de los sacerdotes, la consagración de las iglesias, la consagración de las monjas y visitación de sus conventos, las aflicciones y los clamores del pueblo, y las exequias de los muertos. En el conjunto están presentes, por tanto, las tres series comunes en los sermonarios del siglo XIII: sermones "de tempore", "de sanctis" y "ad status".

La segunda de las obras contenidas en el códice, el Breviloquium de vitiis et virtutibus incluye 15 sermones que tienen por objeto la caridad, la humildad, la paz, la sobriedad, la castidad, la justicia, la misericordia, la paciencia, la oración, el odio, la soberbia, la ira, la ebriedad, la lujuria y la avaricia. Ésta la dedicó frater Egidius a un Pater $M$, episcopus legionense, que el autor arriba citado ha identificado con el obispo Martín de León (1254-1289) 32. Los hechos parecen confirmarlo, puesto que ese prelado, notario que fue de Fernando III, asistió al concilio de Lyon de 1274 y se distinguió por trasladar a su diócesis las directivas emanadas de Roma, lo que llevó a cabo en los sínodos que, bajo su presidencia, se celebraron en León en 1262 (o 1267) y en 1288. El título 47 de los decretos promulgados en la primera de las reuniones facilitó decididamente la predicación de los religiosos en las iglesias ${ }^{33}$.Y aunque en el segundo de los sínodos eludiera el tema y disuadiese el enterramiento de los fieles en las iglesias conventuales, puede entenderse el interés que el franciscano Juan Gil, "custodio" de los menores de Zamora, tendría en asesorar a este obispo en materia de predicación. En cualquier caso, la incorporación de un tratado sobre vicios y virtudes a un sermonario casa perfectamente con el género que, desde el siglo XII, aunaba la teología moral con la retórica de la predicación ${ }^{34}$.

transcritos en adelante en este artículo. (http://88.48.84.154bbw/jsp/volumes).

31 F. Lillo Redonet,Sermonario de Juan Gil de Zamora. Estudio preliminar, edición, traducción y comentario de siete de sus sermones. Zamora, Instituto de Estudios Zamoranos (en prensa). Una síntesis de dicho trabajo se presenta en el artículo precedente de este mismo volumen.

32 La identificación la propuso ya M. de Castro (Lillo Redonet Sermonario...,p. XVII, F. Lillo Redonet basa tal identificación en la forma en que apostrofa a un Pater.

33 Concediendo 40 días de indulgencias a los asistentes a las mismas (A. García y García (ed.), Synodicum Hispanum.III, Astorga, León y Oviedo. Madrid, 1984,, p. 232-253,no 47).

34 Como, por ejemplo, en la Summa de arte praedicandi de Thomas de Chobham (compuesta 
El análisis retórico acometido por F.Lillo detecta una estructura que se reproduce en cada uno de los sermones: thema ( breve pasaje bíblico, localizado a menudo sin demasiada precisión); introductio thematis (con el fin de desentrañar el sentido del tema , y que se cierra con la cita del mismo); divisio (enumeración de las partes que la integra, seguida de una declaratio de las mismas); dilatatio (extensión del contenido del sermón, a través de la exégesis de la Escritura por medio de metáforas, "similitudines" y "exempla", y en ocasiones mediante una prefiguración); y una conclusión final. Dicho análisis no le permite aseverar que Gil de Zamora hubiera llegado a consultar los tratados de Roberto de Basevorn o de Thomas Waleys que, según Charland, configuraron el modelo retórico de las Artes predicandi del siglo XIIII ${ }^{35}$. Admite, no obstante, que, como franciscano, parece difícil que ignorase el Ars concionandi, del llamado Pseudo-Buenaven$\operatorname{tura}^{36}, y$, antes que éste, la estructura general a la que, desde Alain de Lille a fines del siglo XII, venían ajustándose los predicadores en la composición de sus sermones. Un parentesco, o filiación formal más directa del sermonario de Gil de Zamora, en tanto no se analice en su conjunto, y se lo confronte con otras obras contemporáneas (como, por ejemplo, la de Gilbert de Tournai), resulta hoy por hoy imposible de establecer.

Sí puede aseverarse que tal estructura retórica se reproduce en los sermones ad status que incluye el códice de Asís, los diecisiete modelos de sermones para distintas ceremonias protagonizadas por determinados grupos sociales, principalmente del clero secular y regular, y a los que vamos a dirigir nuestra atención. Ajeno a nuestro propósito el análisis retórico, no cabe desconocer algunos aspectos textuales que iluminan ciertos extremos de la autoría, como es el de las "auctoritates" citadas, y de las obras de las que se incorporan frases e incluso párrafos al texto del sermón. Del Antiguo Testamento los préstamos más abundantes proceden de los libros sapienciales, principalmente del Eclesiástico (16 citas), Job (11), Sabiduría (8), Salmos (4), Eclesiastés (4), Proverbios (3), y Cantar de los Cantares (2). Los libros proféticos también están representados: Isaías (8 citas), Jeremías (5), Daniel (1), Zacarías (1), Joel (2), Malaquías (2) y Sofonías (1) . En menor medida, el Pentateuco: Génesis (5 citas), Éxodo (3), Deuteronomio (2) y Levítico

c. 1220)( ed. F. Forenzoni, CCCM, Turnhout, Brepols, 1988). Sobre la retórica de la predicación, cf. M.G. Broscoe,Artes predicandi("Typologie des sources du Moyen Age occidental", fasc. 61). Turnhout, 1992; o bien B.M. Kienzle (dir), The Sermon ("Typologie des sources...", fasc. 81-83). Turrhout, 2000. Una actualización de la investigación sobre predicación medieval, en los diferentes trabajos editados por C. Muessig, Preacher, Sermon and Audience in the Middle Ages: Leiden, Boston, 2002. Cf. igualmente, G.Donavin,C.J. Nederman y R. Utz (eds.),Speculum Sermonis. Interdisciplinary Reflections on the Medieval Sermon. Turnhout, Brepols, 2004; y R. Andersson, Constructing the Medieval Sermon. Turnhout, Brepols, 2007.

35 Th.M. Charland, Artes predicandi. Contribution à l'histoire de la Rhétorique au Moyen Age. Ottawa, 1936,p. 7.

36 S. Bonaventurae opera omnia, t. IX. Quarrachi, 1901,p. 8-21. 
(2). De los libros históricos, apenas acude a Josué (2 citas), Reyes (4), Paralipómenos (2) y Jueces (1). En cuanto al Nuevo Testamento, la principal fuente para el franciscano está constituida por las Epístolas de San Pablo (Timoteo, 8 citas; Corintios, 7;Romanos, 3 , Tesalonicenses, 1 y Filipenses, 1), aunque usa también la de Santiago en tres ocasiones, y una de San Pedro. Los evangelios quedan, así, en segundo lugar: Mateo ( 6 citas), Lucas (3) y Juan (2), seguidos del Apocalipsis (5 citas) y de los Hechos (4).

De la patrología, del autor más utilizado por Gil de Zamora es Bernardo de Claraval, principalmente su comentario sobre el Cantar de los Cantares (7 citas), aunque menudean las citas a otros textos suyos ${ }^{37}$. Le siguen San Agustín, con 12 citas, muy repartidas entre sus obras ${ }^{38}$, Gregorio el Grande, con 5 citas $^{39}$ e Isidoro, con otras tantas ${ }^{40}$. En menor medida utilizó para estos sermones a autores como Jerónimo (Epistola ad Nepotianum), Ambrosio (De virginibus, De viduitate, De penitentia), Próspero de Aquitania (De contemplativa vita) o incluso Sedulio Scoto (Epistola ad Adrianum). Y no faltó la consulta de obras relativamente recientes, como la de San Anselmo (Meditaciones, 3 citas; De similitudinibus,1), el De miseria humana de Inocencio III o el comentario de Hugo sobre el Eclesiastés. Una sola cita hallamos de San Francisco, allegada por transmisión oral (fo $\left.176 \mathrm{r}^{\circ}\right)$. La forma de citar es, con todo, a menudo imprecisa, lo que impide la localización de algunas de estas fuentes ${ }^{41}$.

Utilizadas tales "auctoritates" en la argumentación, por el procedimiento que la escolástica había estandarizado (en un tipo de sermón que ha venido a calificarse como "universitario"), el franciscano aporta el empleo de unas "similitudines" que delatan a menudo su interés en la historia natural. Tratando de explicar las jerarquías políticas, busca la asimilación con el mundo físico: "aurum obedit lune quasi suo seniori sicut patet(...), ferrum obedit adamanti quasi seniori(...), aves aquile vel herodiani, bestie omnes leoni "(fo $\left.167 \mathrm{r}^{\circ}\right)$. Otro ejemplo, tópico por otra parte, es el "sicut a solis procedunt omnes radii et omnia lumina, ita a bona conscientia et honestas que nichil est sordidus ni se appetit contueri procedit bonorum omnium sufficientia", de uno de los sermones "pro conventibus religiosorum" (fo $\left.173 \mathrm{r}^{\circ}\right)$. O algunos otros relativos a la biología corporal ${ }^{42}$.En cualquier

37 De diversos sermones, 3; de cartas, 4; de homilías, 2; del De consideratione, 4; del De Nativitate, 1 ; del De contemptu, 2; de sus Meditaciones, 1.

38 De civitate Dei, 3 citas; Regula ad canonicos, 1;De moribus eclesiasticis, 1;De conversiones sancti Pauli,1;Devita christiana, 1; y las Confesiones, 1 .

39 De la Regula Pastoralis, 2 citas, y del Regestum, 2; Moralia in Job, 1.

40 De los Sinonima, 2 cirtas; Del De summo bono, 1.

41 En dos ocasiones cita a Séneca sin mayor precisión (vgr.:"secundum Senecam cotidie moritur, cotidie demitur aliqua particula vite nostre" (fo $\left.211 \mathrm{r}^{\circ}\right)$; en una a Alcuino, y en otras dos a Aristóteles, en la Epistola a Alejandro Magno.

42 "Et iste clamor est ad modum parturientum...quosque prolem quam habent interius in compaginibus ossium...ita vere contrite anime..."(fo $\left.201 v^{o}\right)$;"sunt abhominabiles ipsi Deo , sicut 
caso, tales referencias a la naturaleza remiten rápidamente a la esfera moral ${ }^{43}$. Frente a esta predisposición hacia los ejemplos tomados del mundo físico, Gil de Zamora apenas utiliza los "exempla” extraídos de la hagiografía, que tampoco emplea en los sermones propiamente "de sanctis" 44 .

Dentro de los 17 sermones ad status nuestro interés se centra, sin embargo, en las parágrafos introducidos por la cláusula sed hodie o huius nostri temporis, con las cuales comienza la exposición de un panorama de la realidad que el autor franciscano contempla en su actualidad como contrapuesta al ideal que está predicando. Abren la serie los dos sermones "pro curiis magnatorum". El primero (fo $166 \mathrm{r}^{\circ}$ $\left.170 \mathrm{r}^{\circ}\right)$ lleva como tema Diligite iustitiam qui iudicatis terram, versículo primero del Libro de la Sabiduría que ya había usado Alain de Lille en el cap. XLII (" $A d$ principes et iudices") de su Summa de Arte predicatoria (PL 210, col. 188-189). Pero la breve argumentación propuesta por el maestro parisino no se respeta en el texto del franciscano de Zamora, que fundamenta en la "divisio" la dignidad y autoridad del príncipe en la función judicial, y correlaciona en la "declaratio partium" las tres formas de justicia con la triple forma -según San Jerónimo- de 1 pecado (contra Dios, contra sí mismo y contra el prójimo), para cada una de las cuales pone como modelo - en la tradición carolingia del concepto de realeza sapiencial ${ }^{45}$ - al rey David. Y en la triple "dilatatio" contrapone al deber de de los reyes una visión de la realidad contemporánea, que, en la primera de las partes, reza así (fo $\left.167 \mathrm{r}^{\circ}\right)$ :

"Reges, principes et barones pre aliis hominibus non obediunt creatori. Isti scilicet equidem nominis christiani duri blasphematores, ecclessiarum et libertatum ecclesiasticarum temerarii violatores, patrimonii crucifixi sacrilegi invasores, in personas ecclesiasticas ausu temerario mittunt manum, et in requisitis episcopis clericos capiunt, trahunt, vulnerant et morte turpissima iugulant et condempnant. Apostatas ordinum ad suas curias

aqua tepida stomacho..." (fo $204 \mathrm{r}^{\circ}$ ); "si quis autem ad senectutem pervenit, statim cor affligitur, caput concutitur, languet spiritus, fetet anelibus, ,facies rugatur, statura curvatur, coligant oculi, vacilant articuli, nares effluent, et orines deficient, dentes putrescunt et aures surdescunt. Et ita..." (fo $214 \mathrm{r}^{\circ}$ ).

43 "Leo et draco, si nocent non nocent nisi tantummodo corpori, mulier vero...", en uno de los sermones dedicados a las religiosas ( $\mathrm{fo}^{\circ} 195 \mathrm{r}^{\circ}$ ).

44 En su lugar, prodiga en ellos las citas y comentarios bíblicos. Los sermones destinados a las festividades de apóstoles, mártires, confesores y vírgenes consisten en moldes generales, válidos para cualquier santo que pertenezca a una de esas categorías , cuyo nombre el predicador que realizara la "performance" podría incorporar en el lugar en que este texto indicaba "festivitatis isti martiris.......", o "festivitatis istae virginis....". En los 17 sermones considerados apenas si se aduce un par de exempla tomados de las Vitae Patrum.

45 Sobre el modelo bíblico de la realeza sapiencial y su glosa altomedieval,cf. M.A- Rodríguez de la Peña, Los reyes sabios.Cultura y poder en la Antigüedad Tardía y la Alta Edad Media. Madrid, 2008 . 
fugientes spirituali prosequunt favore, non permittentes in eos maiores eorum debitam et regularem iustitiam exercere. Inmo protegunt et defendunt iudeos, inimicos crucis Christi, preferunt christianis in negociis regalibus, in vectigalibus, in collectis, in tributis colligendis et distribuendis, in monetis cudendis, rebus locandis, portubus conducendis, in omnibus quibusdam aliis infideles fidelibus auctoritate et potestate regia proponuntur, in subversionem et contemptum fidei christiane et in territum animarum. Nam propter huiusmodi potestates eis christiani cohabitant et etiam conutunt ritos suos et consuetudines. Observantes adeo quod christiani mulieribus infidelibus et infideles mulieribus fidelibus conmiscentur, in subversionem fidei christiane, insuper non curant sacros canones observare de matrimonio contrahendo, taliter quod plures ex eis incesto, stupro, adulterio et fornicatione notorie sunt infecti. Quod in contemptu cultus divini per invocationes demonum, per coniurationes et inmolationes et futurorum promissiones demonibus dedicant semetipsos, iniciationes dierum, horarum, annorum et mensium observantes tanquam malefici incantatores, sortilegi, augures et divini “"”."

En la segunda parte de la dilatatio ("illa iustitia qua tenentur sibi ipsis redere quod suum est, cordi propio equitatem”), al modelo representado también por David, y en cuya exposición se aducen autoridades como Aristóteles, en del "De regimine regni", dirigido a Alejadro Magno, contrapone también la experiencia de su tiempo, sin excluir, a modo de exemplum, cierto aviso en clave bíblica para los reyes peninsulares (fo $168 \mathrm{v}^{\mathrm{o}}$ ):

"Sed hanc iustitiam non exercent hodie reges et principes in se ipsis, quia nec refrenant corpus suum ab impudicis appetibus, nec os suum ab impuris sermonibus, nec totum corpus suum ab operibus impudicis. Inmo ipsi pro aliis hominibus quos debent regere ac tenentur sunt eodem cupidi et ambitiosi, ore vaniloqui et dolosi, opere lubrici et flagitiosi. Et ita igitur ipsis invidiosi pariter et dampnosi, propter iniustitiam quam exercere negligunt in se ipsis, et haec enim frequenter adeo effeminatur, quod et personas suas diffamant et per diuriam iustitiam regnum hereditarium alienant. Sicut patuit in Roboam, filio Salomonis, qui deditus carnalibus deliciis et acquiescens viventibus consiliis factus fuit servus et levis sicut terra sterilis et inculta, et ex hoc amisit maximam partem regni"””.

La tercera de las formas de la justicia, la que el rey ha de ejercer para con el pueblo, en cuya digresión se aduce la autoridad de Alcuino, según un perfil que hace de ella una "iustitia compassiva", dirige una mirada al panorama que, sin duda, se ofrecía a su experiencia peninsular (fo $\left.169 \mathrm{v}^{\circ}-170 \mathrm{r}^{\circ}\right)$ :

"Reges enim nostri temporis non regunt sed potius vastant regna, subiectis sibi populis, duras exactiones et gravamina et importabilia et 
honera imponentes, novas consuetudines inducentes contra libertates et iustitias populorum. Si quis pulchrum equm aut pulchram filiam seu rem desideratam aliam habuerit, et a regibus scitum fuerit, re ipsa desiderabili mox carebit. Tot concubinas possident, non solum christianas sed iudeas et sarracenas, quot placent in occulis eorundem, thoro legitimo postposito et neglecto iusta in amioticas sanctiones. Reges, principes et potentes volutis et libitis involuuntur et perturbato ordine rationis enervant iudicii virtutem, et procuratis iniuriis, consuetudines violente pro iustitia inducuntur, et in partes iustitie advocati id iustum iudicant quod aures inliceat possidentis. Quod a summi iudicis intuitu alieni occulos suos intuitum statuerunt declinare. Nullus est qui pauperi condescendat nisi familiari debito inducatus, sed utinam altissimus videat et permittat et non patientibus sed facientibus inputentur et non luat universitas opressorum quod meretur iniquitas dominorum. Et cessit indignatio magestatis compatiens clamoribus paupertatis eorum qui faucibus dominorum continue devorantur. Iam regna fere omnia in certis angariis seu per angariis cruciantur et tot exactionibus vulneribus sanciantur, quot a summis capitibus usque ad pedes pax remanet inconsumpta."”

La justicia real, tal como había sido concebida por el rey Alfonso X -y cuya administración en la curia regia precisaron las cortes de Zamora de $1274^{46}$ era una realidad que el franciscano conocía de cerca, de ahí que nos resistamos a entender los párrafos transcritos como un mero "topos".Alain de Lille había propuesto también un versículo del salmo II (Erudimini qui iudicatis terram) como tema para otro sermón dirigido a príncipes y jueces, y Gil de Zamora lo desarrolla igualmente, cambiando la argumentación. En este segundo sermón (fo $170 \mathrm{r}^{\mathrm{o}}-172 \mathrm{v}^{\mathrm{o}}$ ), cuya "declaratio partium" consiste en sostener que los jueces deben ser abstinentes, justos y constantes, para todos los cuales erige como modelo al profeta Daniel, Gil de Zamora usa en la “dilatatio” imágenes de la realidad de su tiempo, introducidas generalmente con la expresión "sed hodie". Frente al deber de abstinencia y continencia, dirige la mirada a aquellos

"qui etiam se ipsis miserabiles abutuntur, cum enim alios debeant iudicare nec eosdem ab illicitis actibus refrenare, nec pretermittunt actus inlicitos ad quos non laxent sensus et animos. Cor enim sordidant pravis cogitationibus, delicationibus et consensibus, oculos suos decipiunt vanis pulchritudinibus, aures dulcent melodiis et cantibus, olfatum luxuriosis odoribus, gustum sordidant similiter fluis, cibis et potibus, tactus insiti-

46 Esta asamblea reservó para ser juzgados en la corte real los siguientes casos: muerte segura, mujer forzada, tregua quebrantada, salvo quebrantado, casa quemada, camino quebrantado, traición, aleve y riepto (A. Iglesia Ferrerirós,"Las cortes de Zamora de 1274 y los casos de corte",Anuario de Historia del Derecho Español, 41(1971), 945-72 ; M.A. Pérez de la Canal,"La justicia de la corte de Castilla durante los siglos XIII al XV", Historia, Instituciones, Documentos, 2(1975), 383-481). 
unt multis fornitionibus. Quod idcirco capti tanquam aves tantis deliciis et luxurii nequent intendere iustis iudiciis et honestis" (171 $\left.\mathrm{v}^{\mathrm{o}}-171 \mathrm{r}^{\mathrm{o}}\right)$.

En segundo término, desvirtuando el ideal de ser "prudentes et intelligentes, ne falsis advocatoribus autem sophisticis sermonibus seu cavilationibus decipiantur",

"paucissimi tales iudices reperiuntur hodie in curis principum et magnatorum et etiam in regnorum civitatibus et in villis. Inmo cum nec legem nec forum sciant, nec prudentiam nec eloquentiam habeant, ad iudicatus officium assumuntur "(fo $\left.171 v^{\circ}\right)$.

Y en tercer lugar, la constancia de los jueces se ve desmentida en la realidad porque

"hodie non servant hanc rectitudinem iudices et maiores, inmo deviant a rectitudine sicut regula tortuosa vel ipso vel pretio, hodio vel amore"' (fo $\left.172 \mathrm{r}^{\circ}\right)$.

Aun sin matices respecto de niveles o mecanismos, la imagen moral que Gil de Zamora se hace de la justicia temporal -obtenida por observación en el medio en que vivía ${ }^{47}$ - resulta inequívoca. Tras la justicia, el franciscano decidió dedicar dos sermones a los conventos de religiosos ${ }^{48}$. Para el primero $\left(172 \mathrm{v}^{\mathrm{o}}-175 \mathrm{r}^{\mathrm{o}}\right)$ toma un tema de la epístola a los Corintios ${ }^{49}$, con el que formula la compostura y honestidad que deben presidir la vida de sus miembros, ya que ambas confieren alegría y dulzor a la conciencia del religioso, complacencia o esplendor a su lengua, y fragancia u olor a su fama. El primer término no era, en vida del fransciscano de Zamora, regla general:

"Hoc gaudium honestatis non invenitur in pluribus religiosis, quod sunt tales sicut sepulcra, honesta et pulcra exterius, sed fetida et turpia interius. Ita etiam ipsi honestum portant et album habitum corporis exteriorem, sed tempore gerunt habitum mentis interiorem plenum multis iniquitatibus et vanitatibus infinitis" (fo $173 \mathrm{v}^{\circ}$ ).

47 La imagen, empero, que la historiografía ha presentado de la justicia medieval en España, procedente de fuentes jurídicas, resulta neutra o aséptica: $c f$. M. Torres Sevilla,"Instituciones político-administrativas", en C. Alvarez (ed.),La historia de León. Vol II, Edad Media. Universidad de León, 1999, 39-57.

48 La implantación de los franciscanos fue mayor que la de los dominicos en el reino de León. Instalados ya en Sahagún y Villafranca, hacia 1270 se establecen en León, para fundar poco después en Astorga (G. Cavero,"Iglesia y Cultura”, La historia del reino de León.vol.II, p. 374.

49 "Omnia honeste et secundum ordinem fiant in verbis "(II Corint. XIIII). La "introductio thematis" conforma una metáfora cara al orden regular: "Sicut stella decorat celum et gema pretiosa decorat anulum, ita honestas vite decorat religiosum". 
La corrección del hablar "frivolum et inmundum" es una segunda condición de la honestidad, no exclusiva del religioso, pero que no se da siempre en ellos:

"Sed iam lingua religiosorum multorum non est honesta nec placida nec modesta. Quia et plures ex eis habent linguas plenas scandalum, plenas dolum. Et cum talibus non est loquendi de honestate nec de alia sanctitate" (fo $\left.174 v^{\circ}\right)$.

La fragancia u olor que despide la vida del honesto religioso, glosada por el Eclesiástico y por San Agustín, la echa de menos, por tanto, el sermón franciscano que, no obstante, elude concretar la naturaleza de tales faltas:

"Non est talis vita multorum religiosorum sic videlicet odorífera sed magis fetifera, non vivifica sed mortífera. Quia vita eorum factam est omnibus exemplum malitie, sentina criminum, spectaculum ignominie et totius aversionis forma deformis" (fo $175 \mathrm{r}^{\circ}$ ).

En el segundo sermón dedicado a los religiosos (fo $175 \mathrm{r}^{\circ}-177 \mathrm{v}^{\circ}$ ), glosando un pasaje de la primera epístola de San Pedro ${ }^{50}$, preconiza una triple condición de la "conversatio" del religioso -de altas expectativas, ínfima en su sujeción, y probada por la exhibición de las buenas obras- que tiene su triple manifestación contraria:

"Sed mali religiosi non debent dei sed magis diaboli, quod libentius conversant cum diabolo quam cum domino, magis placet eis conversari cum porcis in luto et fecibus et in foeno quam cum sanctis in celo, magis placet eis domus stercoria quam aula regia, magis placet eis terrena quam gaudia" (fo $\left.175 \mathrm{v}^{\circ}-176 \mathrm{r}^{\circ}\right)^{51}$.

Más explícito en su denuncia se va a mostrar el franciscano en los sermones compuestos para ser predicados en los sínodos diocesanos, de los que el primero (fo $177 \mathrm{v}^{\mathrm{o}}-181 \mathrm{r}^{\circ}$ ) - "Attendite vobis et universo gregi..."-está concebido para ser predicado en los sínodos diocesanos, y se organiza en torno a la triple atención requerida del pastor espiritual: vigilar para que sus ovejas no sean seducidas " a demonibus vel a malis hominibus”; para que no mueran por carencia de predi-

50 "Secundum eum qui vocavit vos sanctum et ipsi in omni conversatione sancti sitis, Petri,I"

51 Respecto a la humildad, los malos religiosos "non sunt subiectione humiles sed superbi, unde sunt imitatores Luciferi non Christi, non considerantes que in soberbia precipicium, in humilitate subiectionis lucrum se ipsos apreciantur, alios dedignantur". En cuanto a exhibir buenas obras, los malos

"sunt tales secundum beatum Franciscum sicut vespera et musca, que non mellificant nec alliud opus bonum frequentant, et tamen quicquid mellis quicquid lactis inveniunt devorant et manducant" (fo $\left.177 \mathrm{v}^{\circ}\right)$. 
cación o doctrina; y para que no caigan en el precipicio del pecado a causa del mal ejemplo dado por aquél. En cada una de las tres partes contrapondrá la imagen del prelado acorde con el modelo prescrito por San Pablo, San Agustín y San Gregorio al espectáculo ofrecido por los "prelati nostri temporis". El más explícito es el que presenta en la "dilatatio" $\left(178 \mathrm{v}^{\circ}-179 \mathrm{r}\right.$ ):

"Sed prelati ecclessiarum dummodo habeant lucrum et emolumentum oblationum, lucrum et emolumentum sacramentorum que venditioni hodie exponuntur, dum habeant emolumenta decimarum et primiciarum, non curant de rapinis seu periculis animarum. Unde ipsi tanquam lupi rapaces et voraces circa comessationes et potationes sanguinum pauperum superfluas et confabulationes illicitas magnam partem noctis expendunt, sompno residuum relinquentes, nichilominus devotioni aut orationi penitus dimittentes. Cumque multis sint impugnati, beneficiis guerras movent cum consanguineis et pro consanguinieis et etiam pro se ipsis. Adeo quod inter ipsos et adversarios grava frecuenter homicidia perpetrantur. Et inmo adversariis talibus subtrahent decimas et oblationes alias videntes se letaliter impeti cum eisdem. Tales prelati mali arma portant prohibita pertingentes ad lites et rixas ubi cedentes, et ipsi ceduntur, et interdum mortis supplicium ipsi luunt. Ieiunia ecclesiastica fugunt ut glutones, quod etiam tempore quadragesimale admittunt ad suas comissationes ioculatrices et cantatrices et publicas meretrices quibus anime comissarum ovium iugulantur. Cumque suas dyoceses visitant de spiritualibus partibus curant. Et adeo ducunt secum superfluos comitatus, ut pretextu harum procurationum clerici remaneant depauperati et ecclessie destitute. Bona frecuenter ecclesiastica ludis scacorum, taxilorum et alearum exponere non formidant, et plures ex eis in sellis et pectoralibus et calcaribus deauratis et vestibus sericatis et aliis superfluitatibus multis tanquam lupi rapaces devorant, et devastant patrimonium crucifixi. Et etiam quod deterius concubinis et laicis et consanguineis et extraneis nepotibus et filiis comittunt ecclesias devastandas. Filios suos et filias tradunt potentibus in conigium, et promovent filios ad militare cingulum, non sine magna et inhonesta dextructione patrimonii crucifixi. Cuius efficiuntur, ut lupi duri raptores et crudelissimi voratores"”.

Una variante de esa imagen la presenta en el sermón "Vos elegit Deus ut sitis semper coram illo..." (181 $\left.\mathrm{r}^{\mathrm{o}}-183 \mathrm{r}^{\circ}\right)$ cuando, al presentar la abstinencia, continencia y ayuno como componentes del perfil moral dibujado por San Bernardo, advierte $\left(f^{\circ} 181 v^{\circ}\right)$ :

"Non sic honorant hodie multi prelati ecclesiarum suum ministerium et officium per abstinentiam, modestiam et sobrietatem sed magis suum vilificant ministerium, suum officium deshonestant, unde sicut pecudes non curant nisi de gula et ventre. Et sicut tabernari non curant nisi de 
taberna, et sicut lucratores non curant nisi de palestris, et sicut aleatores non curant nisi de aleis et taxillis quia sicut ganeones non curant nisi de contubernio meretricum”.

La confección de este sermón alternativo permitía al predicador elegir en el sínodo el modelo a seguir en función de la personalidad de los asistentes a la asamblea. Si no es difícil hallar en el episcopado prelados incontinentes, tampoco lo es encontrar los adictos al juego, un sector regulado por el monarca en $1276^{52}$. Si el sermón anterior va dirigido fundamentalmente a los obispos, éste parece concebido para los canónigos y demás miembros del clero medio, tal como se muestra en la siguiente "similitudo" (fo $182 \mathrm{r}^{\circ}$ ):

"Scutifferi servientes principibus multis sustinent angustias, clerici servientes prelatis multas sustinent vigilias, famuli servientes dominis militibus sive civibus multas sustinent angarias. Et hoc totum faciunt et sustinent patienter propter modicum et transitorium stipendium. Quod igitur et quanta debent pati ecclesiarum prelati propter regem ac pontificem summum a quo in presenti tot receperunt honores et beneficia, dignitates et prestimonia et in futuro expectant ad huc recipere premia inaudita. Certe debent propter ipsius servitium patienter sustinere omne dapnum et incomodum temporale. Ob hoc enim premittit apostolus 'in omnibus exhibeamus nos sicut Dei ministros in multa pacientia'. Plures irent hodie Romam et ieiunarent in pane et aqua per unum mensem vel per unam hebdomadam si scirent per hoc posse acquirere sibi unam transitoriam canoniam. Et si hoc faciunt per una canonia temporali et transitoria, quantum debent sustinere per canonia celica et eterna"”.

Nuestro conocimiento de los sínodos diocesanos celebrados en el entorno de Gil de Zamora coetáneamente, o con alguna posterioridad, a la composición del Liber sermonum no es suficiente como para decidir cuál de los dos se predicaría en cada caso. En la diócesis de Zamora, en Toro, celebró una asamblea de este tipo el obispo Suero Pérez $(+1286)$, consejero de Alfonso X, aunque militaría en el bando rebelde que apoyó al infante Don Sancho. En ella se adoptaron acuerdos más exigentes para con los fieles que para con el mismo clero ${ }^{53}$. Pero Zamora era diócesis sufragánea de la de León, donde el prelado Martín Fernández

52 "To safeguard public moral" ( R.A. Mac Donald (ed.), Libro de las Tahurerías. A Special Code of Law concerning Gambling, Drawn up by Maestro Roldan at the Command of Alfonso X of Castile. Madison, 1995,p. 29.

53 Que los clérigos compelan a sus parroquianos a abstenerse de ilícitas uniones de pareja; que registren las posesiones de sus iglesias y las adquiridas por los religiosos tras el concilio Lateranense, y que las parroquias perciban la mitad del diezmo a la iglesia de quienes cambien de residencia (A. García y García Synodicum Hispanum IV. Madrid, 1987,p. 431-433. 
(que la gobernó entre 1254 y 1289) celebró un sínodo hacia 1267 que impuso mayor rigor en el estamento (legislando sobre el hábito, cumplimiento del rezo litúrgico, prohibición de usuras y supersticiones...), limitando la intervención de los patronos laicos en las provisiones y sometiendo todos los niveles clericales a la supervisión de los obispos ${ }^{54}$. El título 47 otorgaba 40 días de indulgencia a aquienes asistiesen a la predicación y a las confesión de los frailes mendicantes.

Imbuido de ese programa, y para amonestar al clero secular en las grandes ocasiones rituales, el franciscano incluyó en el sermonario dos piezas destinadas a las primeras misas de los presbíteros ("pro misis nouis seu sacerdotibus nouis"), y otras dos a la consagración de iglesias. El combate al beneficialismo, por la valorización de la función sacerdotal u oficio, sostenido por la iglesia a lo largo de la era gregoriana, justifica la elección del versículo del Eclesiático,VII, "Honorifica sacerdotes" como tema del primer sermón (fo $183 \mathrm{r}^{\circ}-186 \mathrm{r}^{\circ}$ ). En cuatro "rationes" sustenta el deber de honrar a los sacerdotes que tienen los hombres: en que son sus padres, sus doctores y maestros, sus señores y sus médicos espirituales. La filiación "espiritual" no le parece realidad universal"5 , como tampoco el respeto al magisterio espiritual:

"Sed hodie, peccatis exigentibus, frequenter plus honorant homines unum pastorem caprarum quam unum capellanum pastorem animarum, plus honorant unum sutorem quam unum sacerdotem doctorem, quod non deberent facere etiam si sacerdotes essent mali"'”(fo $\left.184 \mathrm{v}^{0}\right)^{56}$.

La trascendencia civil del sacerdocio es, despreciada ${ }^{57}$, más que las connotaciones taumatúrgicas expuestas en la quarta "ratio", que, además de incluir uno de los pocos "exempla" registrados en los sermones, delata, en el primer término de la "similitudo", la especificidad de la formación universitaria del franciscano:

"Homines mundani honorant precibus et muneribus medicum corporalem propter sanitatem corporum, honorant cirurgicum propter sanitatem vulnerum, honorant apothecarium propter necessitatem electuariorum, honorant unguentarium propter necessitatem unguentorum.

54 Synodicum Hipanum...;III (“Astorga, León y Oviedo”),p. 232-253.

55 "Sed hodie non curant spirituales filii de parentibus supradictis nec propter longevitate vite ne propter benedictionem celestis glorie, nec propter stabilitatem generationis posterioris, inmo affitiunt ipsos plagis verberibus valde duris" (fo $184 \mathrm{r}^{\circ}$ ).

56 Siendo así que "Mundani homines honorant doctores suos qui eos docent gramaticam vel logicam vel ius canonicum vel civile, honorant etiam instructores suos qui eos instruunt in arte pelliparia vel sutoria" (ibidem).

57 "Ad imperium sacerdotum debent christiani sacramenta ecclesiastica suscipere, de conmissis satisfacere, omisa restituere, a heresibus precavere, sententias custodire. Et haec debent sacerdotes inducere populum verbis, monitis et exemplis" (fo 185\%). 
Quarum haec totum faciunt propter corporum corruptibilium sanitatem. Igitur si sanitas spiritualis nobilior est quam corporalis, magis debent homines honorare medicum spiritualem quam corporalem. Et idcirco premittit sapiens "Honora medicum propter necessitatem". De hac necessitate loquitur Jacobus, V, 'eiusdem infirmatur quis in vobis inducat presbiter ecclesie et orent pro eo ungentes ${ }^{58}$ illum in nomine domini, et oratio fidei salvabit infirmum et allevabit eum dominus. Et si in peccatis fuerit dimittetur ei'. Oratio enim boni sacerdotis non solum infirmum sanat sed et mortui vitam impetrat. Exemplum de sacerdote in vinea laborante, vocato ad audiendum quondam infirmum de confessione, qui dum iret interim expiravit, et post ad preces eius revixit et curatus est. Sacerdos enim debet gerere vicem spiritualis medici. Subditus debet gerere vicem spiritualis egroti sicut enim materialis physicus accedens ad egrotum proprio verbo materialem egrotum conpatitur, egroto se conformat, infirmo verbis blanditur, salutem pollicetur, ut eger confidencius detegat morbi quantitatem, doloris acredinem. Consequenter inquirit tempus cum morbus inceperit, locum ubi eum morbum arripuit, etatem cuius etatis sit, sestum etiam disquirit causam morbi et originem, morbi diuturnitatem, vivendi consuetudinem, persone statum, pulsus impetum, corporis gestum, faciei habitum. Deinde, cognitis morbi circunstantiis et accidentibus infirmitatis, medicus secundum morbi quantitatem dietam magis aut minus extenuat, quosdam cibos vetat, alios imperat. Egroto vero peius promittit nisi iniuncta custodiat, consequenter contrariis contraria curat"” (fo $\left.185 \mathrm{v}^{\mathrm{o}}-186 \mathrm{r}^{\mathrm{o}}\right)$.

El otro sermón destinado a las primeras misas (fo $186 \mathrm{r}^{\circ}-189 \mathrm{r}^{\circ}$ ) no contempla el sacerdocio desde una perspectiva exterior, sino más bien en sí mismo, para lo cual a partir de un versículo de Proverbios, 14 ("Acceptus est regi minister intelligens") propone un triple perfil para los aspirantes a ese ministerio: limpieza de corazón, disposición a la acción y honestidad en "vita et conversatio". Todo indica que el texto fuera concebido para ceremonias más íntimas, con menor asistencia de laicos, y quizás por ello las referencias al mal presente, aunque no carentes de severidad, quedan en términos más generales ${ }^{59}$.

La consagración de iglesias conforma otra liturgia que, en el último cuarto del siglo XIII, había de reproducirse en no pocos templos del orden secular y de las órdenes mendicantes en la península ibérica, y por ello tuvieron su doble

58 "ut gentes" en el mss. Cf. Ep. Santiago, 5-14.

59 "Sed hodie...cor habent inmundum et carnem dominici sacerdotes" $\left(187 \mathrm{r}^{\circ}\right)$, "non sunt strenui, sed pigri et remissi, non vigilantes sed dormitantes, non laboriosi sed ociosi, non evangelicantes sed evangelium evacuantes, non consumantes bona opera inchoata sed imperfectam relinquentes, non sobrii sed gulosi et ebrii" (fo $188 \mathrm{r}^{\circ}$ ), "non enim exhibent se ministros Dei sed diaboli, non Christi sed antichristi, qui oves sibi conmissas per bonum exemplum ad se non atrahunt, sed magis per malum exemplum dispergunt, reiciunt et repellunt" (fo $\left.188 \mathrm{v}^{\circ}\right)$. 
representación en el sermonario. La primera pieza ("Elegi locum istum michi in domum sacrificio",Paralippomena, VII) justifica, a través de las tres "rationes", la elección divina del lugar del templo: por ser espacio donde se le adore y honre, donde se custodie de manera especial su memoria, y donde se le ofrezcan sacrificios gratos. Exigencias que distaban de constituir la norma:

"sed, peccatis exigentibus, non sit hodie in ecclesia debita oratio, sed potius execratio, non est ibi devotio sed derisio. Cum enim in ecclesia deberent intendere christiani divinis laudibus, hymnis, psalmis et canticis spiritualibus, intendunt pocius vanis fabulationibus, machinationibus, illusionibus et detractionibus"(fo $\left.190 \mathrm{r}^{\mathrm{o}}\right)$.

En la "dilatatio" de la segunda razón -el templo como lugar de memoria- Gil de Zamora elude el habitual panorama negativo y presenta en cambio dos argumentaciones de naturaleza semiológica y larga tradición en la cultura cristiana: el motivo y fin de la introducción de imágenes en las iglesias y el significado del ritual de consagración realizado por el obispo ${ }^{60}$. Y el desarrollo de la tercera -"ut ibidem sacrificum gratum domino offeratur"- lo aprovecha para, veladamente, amonestar acerca del adecuado destino del diezmo: "auferunt enim homines ecclesie in modo decimas et primicias, oblationes et iurisdictiones alias, que debent esse in usu et sustentationem eorum qui serviunt regi Xristo "(fo 191vo).

El segundo sermón $\left(191 \mathrm{v}^{\circ}-193 \mathrm{v}\right.$ ) $)$, desarrollado a partir del versículo de los salmos "Domum tuam, domine, decet sanctitudo", resulta de menor altura, y parece como destinado a santuarios rurales o de pequeña entidad. El autor se limita a preconizar el deseable decoro del templo, ya que Cristo desea servidores "mundos seu limpidos"(I), comensales santos (II), así como un adecuado "hospicium" para comer y dormir (III). Todo lo cual no le parece la tónica habitual : "nec mundis vasis, nec mundis manibus, nec mundis vestibus serviunt coram Deo" $\left(192 \mathrm{v}^{\circ}\right)$, "mensa in qua reponuntur cibi corporales mundior custoditur" (ibidem), "unde non videtur oratorium divinum sed stabulum iumentorum" $\left(193 \mathrm{v}^{\circ}\right)$.

De manera no subsecuente a los de los religiosos (como sería lo lógico desde la perspectiva actual), sino después de los relativos al clero secular, Gil de

60 "ut simplices qui non possunt scripturas legere...", pero también "propter afectuum tarditatem ut videlicet homines qui non excitantur ad devotionem..." (fo 190vo). Tras el largo debate sobre la iconoclastia, el apoyo en las imágenes era en el siglo XIII una especialidad franciscana: "one thinks first of franciscans when considering the preacher's evocation of visual pictures" (D'Avray, The Preaching...,p. 105. Sobre el ritual de consagración, las doce luminarias y las doce cruces son colocadas en memoria de los apóstoles; el hisopo sobre el báculo rememora al mismo Cristo en la cruz; la triple llamada a la puerta por el obispo recuerda cómo Cristo, tras la ley natural y la mosaica, venció al maligno por la ley evangélica; las escrituras en los cuatro ángulos, la universalidad de la predicación, y el agua bendita con sal y ceniza y vino significan el antídoto ofrecido al género humano (fo $\left.190 \mathrm{v}^{\circ}-191 \mathrm{r}^{\circ}\right)$. 
Zamora incluyó en su colección dos sermones destinados a las monjas, concretamente "pro consecratione et visitatione monialium". En el primero ("Pars bona mulier bona"), destinado específicamenente para la ocasión de la visita de los conventos, establece el perfil de la mujer buena: sincera y humilde "propter honestatis splendorem" $\left(194 \mathrm{r}^{\circ}\right)$, tímida y temerosa "propter divine iustitie rigorem et sue fragilitatis considerationem" $\left(195 \mathrm{r}^{\circ}\right)$, y muy fuerte "in agrediendo quaecumque opera optima pietatis" $\left(195 \mathrm{v}^{\circ}\right)$. A esta tríada contrapone otras tantas realidades "huius nostri temporis": respecto del primer término, contempla las que son"effrontes, sine verecundia, sine reverentia, sine aliqua honestate". Frente a la segunda virtud, la mujer temeraria "comparatur...bestie silvestri quod...omnes alias bestias depredatur et nunquam saciatur". Y frente a la tercera cualidad, la mujer mala es "debilissima et mollisima sicut cera".Observaciones más concretas del panorama moral de las religiosas pueden hallarse en el sermón destinado a ser predicado en la ceremonia de consagración de las monjas $\left(196 \mathrm{v}^{\circ}-199 \mathrm{r}^{\circ}\right)$. Tras establecer los requisitos exigibles a las que se han de consagrar: integridad del cuerpo (virginidad) y pureza del alma; solicitud, diligencia y laboriosidad; devoción y fervor en la oración ("pro parentis suis et aliorum, maxime illorum quorum ecclesias receperunt"), Gil de Zamora opone otras tantas imágenes de la realidad percibida por él. Respecto al segundo aspecto, puede asegurar:

"sed iam hodie paucissime tales virgines reperiuntur qui sint laboriose et studiose circa opera monasterii, inmo sunt negligentes et ociose nisi circa delicias propri subiecti. Et idcirco comparantur vespis, quod sicut vespe nunquam mellificant sed tantum mel devorant et manducant, et mellificantes apes cruciant et necant, et ita virgines otiose splendide volunt comedere, quiete dormire, verbis otiosis intendere sed nichil virtutis aut operis in monasterio exercere".

Mucho menos explícito se muestra, sin embargo, contraponiendo al primero de los aspectos la realidad de la vírgenes fatuas -sobre las cuales versa una extensa "dilatatio", sazonada de citas bíblicas, e incluso el paragón con la condición felina ("et sunt sicut catus, pulchram habens pellem, qui propter pulchritudinem et vanitatem incurrit ipsius pellis excoriationem et mortalitatem").Con delicadeza el franciscano obviaba cualquier insinuación explícita sobre las realidades mundanales, escabrosas incluso, que podían penetrar hasta en un convento femenino, tal como lo muestra el asunto destapado en 1279 en el convento de las Dueńas, de Zamora, donde una serie de religiosas fueron sorprendidas en comercio carnal con varios frailes dominicos ${ }^{61}$

61 cf. P. Linehan, The Ladies of Zamora. The Pennsilvania State University Press, 1997,p. 41-66. Acerca de la predicación dirigida específicamente a las mujeres, cf. C. Casagrande (ed.),Prediche alle 
Género distinto de sermón lo componen los "tangentes afflictiones, clamorum popularium pro pluviis, videlicet vel siccitate seu quacumque alia tempestetate" $\left(199 \mathrm{r}^{\mathrm{o}}-203 \mathrm{r}^{\circ}\right.$ y $\left.203 \mathrm{r}^{\mathrm{o}}-205 \mathrm{r}^{\circ}\right)$. El primero se articula en torno a las cuatro formas de clamor humano, y es en la tercera, la de los "afflicti et tribulati", que claman a Dios "per cotidianam orationem" donde aborda el problema de las rogativas por lluvia desatendidas, y aduce el ejemplo, sacado de las Vitae patrum, del anciano que fue interpelado en el Sinaí a propósito de ello y que, "manus ad celum orans devotiissime", obtuvo la llegada de tan esperado don. "Sed hodie multi sunt adeo in oratione tepidi qui non merentur a domino exaudiri. Adeo clamant sub misse et orant remisse, quod eorum deum amorem totius non exaudivit”, asevera Gil de Zamora. El segundo sermón es más místico, por cuanto lo divide según una triple forma de oración: "ferventer et diligenter", "discrete ac sapienter" y "perseveranter, firmiter et constanter". La segunda modalidad consiste en considerar el "modum, tempus ac locum", lo que implica acercarse a Dios sin lascivia, soberbia o envidia,y hacerlo "in locum honestum" et tempore congruum".

"Sed hodie, peccatis exigentibus, multi sunt qui non habent modum inquerendo Deum, et idem non inveniunt eum nec ipse exaudit eos (...). Et ipsi sunt tales sicut ille qui querit racemos in via post tempore vendimiarum(...). Sunt et enim hodie multi sicut stultus infirmus qui tamdiu differt querere medicum quamdiu incurrit mortis periculum. Ita et nos curamus usque quo tempestatis vel infirmitatis seu cuiuscumque alterius adversitatis videmus periculum invenire, quibus dominus conminatur dicens "Io,Io, queritis me et non invenietis".

La finalidad de estos dos últimos sermones parece clara: espiritualizar las rogativas del tipo "ad petendam pluviam" -paulatinamente insertas en un marco diocesano a medida que, desde mediados del siglo XIII, declinaban las peregrinaciones a las tumbas de los santos-, para insertarlas en un contexto de piedad asidua, y despojarlas del efecto decepcionante de las que no se veían seguidas inmediatamente por el beneficio pluviométrico. Y en Castilla y León no deberieron faltar las ocasiones para tal predicación, en una época signada por el cambio de coyuntura agraria, en la que las adversidades climáticas, y demás factores coadyuvantes al malestar agrario se hicieron particularmente lacerantes ${ }^{62}$.

donne del secolo XIII: testi di Humberto da Romans, Gilberto de Tournau, Stefano di Borbone. Milán, 1978; S. Khan, "Ave- Eve.Views of Women: Social and Gendered Instruction in Medieval and Early Modern European Preaching", The Medieval History Journal, (ap. 2004),v. 7,no 1109-135.

62 Sin embargo, la crisis de subsistencia de 1257-60, general en toda Europa, y que se reprodujo entre 1276-78, está mejor documentada (en sus efectos) para Galicia que para el reino de León (A. Rodriguez López, "Carestías y subsistencia en el noroeste peninsular en los siglos XII y XIII", en H.R. Oliva y P. Benito(ed.),Crisis de subsistencia y crisis agrarias en la Edad Media. Universidad de Sevilla, 2007, 199.221,p. 205 y passim. 
La serie de los sermones "ad status" se completa con tres muestras de los "tangentes exequias mortuorum". El culto funerario llevaba tres siglos ritualizado en unos términos que las órdenes mendicantes se esforzarían, como en tantos otros aspectos de la "instructio fidei", en espiritualizar a través de la predicación ${ }^{63}$ . Para el primero y más extenso de los sermones (fo 205ro-209ro ) elige Juan Gil como tema el versículo del salmo "Homo sicut fenum dies eius tanquam flos agri sic efflorebit", que le da pie a una cuádruple distinción en torno al tema de las mutaciones del cuerpo humano, desde su concepción misma hasta la muerte. Despliega aquí el franciscano una amplia, y de alguna forma original, dilatatio en la que resuena el eco de su inclinación a la historia natural, empezando por analizar la materia misma con la que fue formado el hombre:

"Qui comprimere desiderat et constringere supercilium cordis sui debet considerare radicem ex qua procedet originaliter. Debet considerare maternum uterum in quo conceptus fuit materialiter, debet considerare quomodo totum tempus vite sue consumpsit et expendit miserabiliter. Debet considerare nichilominus quo tendit et quid de ipso fiet finaliter. Et secundum haec predicta reperiet quod homo fuit lutum sordidum, semen fetidum, vanitas umbratilis, pulvus vermis et cinis. Homo fuit lutum sordidum in primatia plasmatione, fuit semen fetidum in conceptione et vanitas umbratililis in duratione, sed erit pulvis et cinis in resolutione" (fo $\left.205 \mathrm{v}^{\circ}\right)$.

Enlasegunda "ratio et consideratio" tratapropiamentedelaformacióndelcuerpo:

"Si desideras agnoscere materiam ex qua sunt in conceptione in modus, audi sapientem humiliter profitentem. Coagulatus sum in sanguine matris et ex semine patris et per deliramentum sompnii conscientis tam a parte patris quam a parte matris. Quia in conceptu proles per decisionem seminum consopiuntur sensus racionales sicut in sompno sensus corporales. Et homo efficitur totus caro. Et sicut videmus quod lac prius mulgetur ab ubribus, deinde coagulatus tandem caseus formatur, ita semen matris quod est sanguinolentum......et semen patris quod est candidum lumbus paternis primitiis deciduntur, deinde in materno utero coagulantur et in sanguinem convertuntur, ex quibus homo compaginatur" (fo 206vo).

Se trata de un dominio en el que Gil de Zamora se movía a gusto, si se considera la magna Historia Naturalis que compuso entre 1275 y 1295 , en la que de-

63 Cf. J. Berlioz y C. Ribaucourt,"Mors est timenda. Mort, morts et mourants dans la predication médiévale: l'exemple de l'Alphabet des récits d'Arnold de Liège(début XIVè s.)", en Alexandre-Bidon(ed.), À reveiller les morts. La mort au quotidien dans l'Occident médiévale. Lyon, 1993,p. $17-30$. 
scribe enfermedades y recoge remedios terapéuticos ${ }^{64}$. En la tercera de las razones del actual sermón, acudiendo ampliamente al libro de Job (pero también en la carta de San Bernardo al papa Eugenio III, o en el De miseria humana, de Inocencio III), el franciscano medita sobre la vanidad de la existencia humana, repleta de muchas miserias, temporales y espirituales, entre las que cita la ira, la envidia, la ebriedad, la lujuria, la avaricia, la voluptuosidad, la curiosidad y el temor. Con base en el Ecclesiastés y en San Gregorio, consagra la cuarta razón -destinada a "confringere superbiam cordis"- a la meditación de las postrimerías, para concluir parafraseando el Libro de la Sabiduría, en una ironía acerca de la disputa de los mendicantes con el clero secular por los legados testamentarios:

"si desideras agnoscere quibus corpora nostra testamentarie legabitur, audi quid sapiens concludit: cum morietur, homo heredabit serpentes, bestias atque vermes. Corpus suum hereditatem dimittet serpentibus, bestiis et vermibus. Ab hiis enim in multis terris calidis carnes hominum corroduntur et consumuntur in vermes et in buffones carnes convertuntur" $\left(208 v^{\circ}\right)$.

El segundo de los sermones de este género (fo 209ro-211 $\mathrm{r}^{\circ}$ ) adopta como tema otro versículo de los salmos:"Homines periebunt, tu autem permanebis". Su mayor brevedad parece hacerlo más apto para funerales de menor cuantía, aquellos en los que la composición de la audiencia no exigía mayor demora en especificar las miserias humanas ${ }^{65}$. Más allá de la estructura retórica explícita en la contraposición 'condición débil y lábil del género humano'/'inmortalidad e inmutabilidad del creador', ya en la primera "dilatatio" se advierten expresiones indicativas del carácter popular de la audiencia:" "Quamdiu sumus et vivimus in hoc mundo confidimus et speramus de mundanis operibus, de mundanis potentibus et honoribus. Confidimus nichilominus de bonis naturalibus" (fo 209vo). Y algo más adelante, al expresar la caducidad de los bienes y honores temporales, utiliza el siguiente "exemplum", apropiado visiblemente para una audiencia burguesa:

"contingit enim navigantibus et laborantibus pro diviciis huiu mundi sicut contingit cuidam usurario in hac die postquam enim cum multis laboribus multas pecunias aggregavit et possesiones plurimas comparavit, magna sibi palatia edificavit, cumque disponeret in hiis in quibus laboraverat et sudaverat requiem sibi dare".

64 Cf. Johannes Aegidius Zamorensis, Historia Naturalis. 3 vols. (edición y estudio de A. Domínguez García y L. García Ballester). Salamanca, 1994. También,L. García Ballester y A. Domínguez,"The Medical World of Juan Gil de Zamora's Historia Naturalis (ca. 1275-1296), Dynamis, no 14(1994), 249-67.

65 Cf.D.L.D'Avray, The Preaching of the Friars. Sermons diffused from Paris before 1300..Oxford, 1985, esp. p. 104-131:"'The problem of Audience and Function" 
En una segunda distinction afronta el fin de la gloria y la memoria humana, ejemplificándolo en el caso de aquellos altos personajes a quienes ni siquiera había hecho alusión en el anterior sermón:"Perit memoria eorum cum sonitu cum moritur aliquis magnus homo. Rumor sonitus et strepitus per plateas volat et per vicos. Ecce imperator mortuus est, aut filius imperatoris, rex aut filius eius, postquam non sepelitur cum strepitu lamentorum et lamentatricum, cum illo sonitu memoria eius perit”. Y la tercera razón, donde divaga acerca de lo perecedero del cuerpo y el alma humana, termina con una cita del De similitudinibus de San Anselmo (fo $211 \mathrm{r}^{\mathrm{o}}$ ) para describir la gloria eterna ${ }^{66}$, concluyendo "que pacientia pauperum non peribit in finem, inmo finaliter ad eternam gloriam permanebit".

Para el tercero de los sermones funerarios, en que se contrapone la vida futura a la presente, elige una frase de la epístola de Santiago: "Vita nostra vapor est ad modicum parens". No es sólo su gran extensión (fo $211 \mathrm{v}^{\mathrm{o}}-215 \mathrm{v}^{\mathrm{o}}$ ), sino sobre todo, la profusión de citas de la Escritura y la patrística con que lo adoba ( Séneca, San Juan, Job, Bernardo -De consideratione ad Eugenium papam- , Job, Eclesiastés, Bernardo -"quibusdam dictis suis"- Job, Bernardo-"sermone LXXV”, Anselmo -Meditationibus-, Ecclesiastés, Bernardo-De consideratione...-, Sabiduría, Ecclesiástés, Bernardo-quibusdam dictis...- , Job, Bernardo- super psalmus Qui habitat, "sermone LXXV"-, Anselmo-Meditationibus-, Ecclesiastés, Epist. Cor., el comentario de Hugo de San Víctor sobre el Ecclesiastés, Anselmo-Meditationibus-, Ecclesiástico, Agustín -De civitate Dei-, Sabiduría, Job, Agustín, Salmos, Bernardo -Meditationibus-, Epist. Thimoteum, Isidoro, Agustín-De civitate Dei-, Ecclesiastés, Séneca, Jeremías, Anselmo-Meditationibus) lo que nos señala el destinatario clerical de su composición.

En la primera división $\left(211 \mathrm{r}^{\mathrm{o}}-\mathrm{v}^{\mathrm{o}}\right)$ realiza una historia natural de la miseria humana, desde el útero materno ("felices illi qui moriuntur ante quam oriantur prius mortem sentientes quam vitam istam scientes"), para continuar (fo $212 \mathrm{r}^{\mathrm{o}}$ ) por la historia social, en un catálogo de las actividades humanas (o de las artes y oficios, tal como se le representaban a un castellano del siglo XIII) tendente a glosar la vanidad proclamada en el Eclesiastés:

"currunt namque et discurrunt miserabiles homines per sepes et semitas, ascendunt montes, trascendunt colles, transvolant rupes et alpes, ingreduntur foveas et cavernas, rimantur viscera terre, profunda maris et fluminis , opaca nemoris in via sollicitudinis, et deserti exponunt se ventis et imbribus tonitruis, fulminibus ${ }^{67}$ et procellis, metalla cuddunt et conflant,

66 "ubi (gloria eterna) erit omnis pulchritudo, agilitas, fortitudo, libertas, sanitas, voluptas, longevitas, sapientia,amicitia, concordia, honor, potestas, securitas, et gaudium eternum, intus et extra totam animam inebrians, satians, et quietans in ipso summo et interminabili bono cui est honor et gloria per infinita secula seculorum amen" (fo $211 \mathrm{r}^{\circ}$ ).

67 'fluminibus' en el mss. 
lapides sculpunt et polluunt, ligna cedunt et dolant, telas ordiuntur et texunt, vestes inciduunt et consumunt, edificant palatia, plantant viridaria, colunt agros, pastinant vineas, succedunt clibanos, construunt molendina, piscantur, venantur, aucupantur, mercantur, litigant, preliantur, decipiunt, diripiunt et furantur, et multa consilia faciunt ut divitias habeant, honores, potentias, dignitates et in hiis omnibus labor et afflictio" $\left(212 \mathrm{r}^{\circ}\right)$.

Dedicada la segunda división a la transitoriedad de la vida presente, su retina naturalista le lleva a dilatar describiendo la decrepitud del cuerpo humano envejecido:

"si quis autem ad senectutem pervenit statim cor affligitur, capud concutitur, languet spiritus, fetet anelitus, facies rugatur, statura curvatur, caligant oculi, vacillant articuli, nares effluunt et crines deficiunt, dentes putrescunt et aures surdescunt. Et ita pertransit humana sanitas sicut nubes. In eo quod subdit sapiens quod vita hominis sicut nebula dissolvetur. Innuit quod nebula que ex variori vapore generatur, quod nubes per solares radios subito elevatur, et a calore solari iterum adeo aggravatur, quod ad sinus terre ubi dissolvetur et nullum posterie vestigium derelinquit. Ita complexio humana per calorem febrilem cito dissolvitur, et homo a vita presenti fugatur et descendere cogitur ad sepulcrum, et qui non fuerit ita memoria eius perit" (fo $214 \mathrm{r}^{\circ}$ ).

La disputa entre los mendicantes y el clero secular por la gestión del culto funerario explica el énfasis franciscano en la predicación de las exequias de los muertos, un terreno que la investigación española apenas ha cultivado ${ }^{68}$.

La serie de sermones examinados configuran, dentro del Liber sermonum, un ciclo que Gil de Zamora compuso entroncándolo, evidentemente, con el modelo de los sermones ad status, subgénero del que, a fines del siglo XIII, sólo habían aparecido tres muestras en el occidente medieval: las de Humberto de Romanos, Jacques de Vitry y Gilbert de Tournai ${ }^{69}$. La primera de ellas ${ }^{70}$ no es, a todas luces, la fuente de inspiración de nuestro autor. De los otras dos autores, dominico y franciscano, podríamos pensar que el segundo, maestro regente de la facultad de teología de París una década antes de la estancia en ella de Gil de Zamora ${ }^{71}$, pudo

68 Los obituarios y libros de los aniversarios y memoriasde las iglesias y monasterios españoles apenas si han sido analizados para otros aspectos que el estudio de la formación de los patrimonios. Para Europa, en general, $c f$. D. Alexandre-Bidon,La mort tau Moyen Age(XIIIè-XVIè siècles). Paris, 1998. Cf. igualmente R. Huntingdon y P. Metcalf,Celebrations of Death. The Antropology of Mortuary Ritual. Cambridge University Press, 1991; M. Lauwers,La mémoire des ancêtres, le souci des morts: morts, rites et société au Moyen Age. Beauchesne, 1997.

69 D'Avray, The Preaching...,p. 127.

70 Cf. supra, nota 25.

71 Concretamente entre 1259-1261 ( D’Avray, The Preaching...,p. 145). Gil de Zamora acudió 
haber ejercido alguna influencia sobre el sermonario de éste, pero ello aguarda aún la investigación.

La cuestión filológica del grado de originalidad del autor adquiere relevancia cuando se trata de valorar la importancia de la obra como fuente histórica. ¿Constituyen los párrafos introducidos por sed hodie un "topos" dentro del género de los sermones "ad status", o son expresión de la visión personal del autor del sermonario acerca de la sociedad de su tiempo, aquella de la que él mismo tiene una percepción directa?. Aun considerando el contexto general al que remiten los sermonarios (como cualquier obra literaria latina) ${ }^{72}$, parece, sin embargo, que Gil de Zamora tenía en su retina la sociedad hispana de su tiempo cuando compuso la colección de textos para ser predicados ${ }^{73}$. Tratándose de modelos para ayuda de los predicadores que, al pronunciar el sermón en lengua romance, acomodaban al auditorio su ejecución, sus términos no podían ser sino muy generales. Máxime si debían servir para una utilización prolongada en el tiempo. Y esto último les resta valor informativo acerca de las coyunturas. De la serie analizada, sólo los sermones dirigidos a los sínodos suministran una información susceptible de contraste cronológico.

Aun admitiendo la "escasa originalidad" que se ha atribuido en un artículo de este mismo volumen a los sermones de Juan Gil de Zamora ${ }^{74}$, no puede por más tiempo suscribirse la observación de una obra tan influyente como la de D.L. d'Avray respecto a la importancia alcanzada por el género homilético en el siglo XIII hispano ${ }^{75}$. Inaugurado de manera brillante, con Martín de León, en el período inicial de las escuelas clericales, la predicación quedó visiblemente rezagada en Espańa durante el florecimiento universitario del siglo XIII, pero desde los años setenta hay ,en las órdenes mendicantes, al menos dos testimonios de un esfuerzo por incorporarse al acervo general de la cristiandad latina. En ambos

a París hacia 1273 (Pérez-Embid,Hagiología...,p. 304). En cualquier caso, es preciso considerar la hipótesis de una "Paris franciscan tradition of aids for preachers" formulada por D'Avray (The Preaching...,p. 146). Cf. , ibidem,p. 260-271, la edición del "Ad cives communiter viventes sermo" de Gilbert de Tournai.

72 "Mendicant model sermons (and other preaching aids) of this period were normally transmitted in Latin, wich gave them what might be called a spaceless character: they were not tied to local or national contexts. Paradoxically, Latin transmision left more room for the preacher's initiative"(D'Avray, The Preaching...,p. 128).

73 Como cuando observa que los reyes "tot concubinas possident, non solum chriatianas sed iudeas et sarracenas" ( $c f$. supra y fo $170 \mathrm{r}^{\circ}$ ) , circunstancia que sería más visible en la corte castellana que en otras ultrapirenaicas.

74 Cf F. Lillo Redonet,. art, cit., p. 101.

75 "The contribution of Spain and Scandinavia to mendicant preaching literature of this period was negligible, or remain unknown, to judge by the silence of these two countries in the section on "Die Volkspredigt des 13. Und 14. Jahrhundertsin Schneyer's Geschiichte ,p. 154-171 (D.L.d'Avray, The preaching of the friars. Sermons diffused from Paris before 1300. Oxford, Clarendon Press, 1985,p.154,n. 2). 
casos, dominico y franciscano, no faltaba la formación intelectual adquirida en las universidades francesas. Tampoco una percepción muy nítida de la sociedad de su tiempo. 